\title{
Harmful impact of filamentous algae (Spirogyra sp.) on juvenile crayfish
}

\author{
Dariusz Ulikowski, Łucjan Chybowski, Piotr Traczuk
}

Received - 28 September 2015/Accepted - 27 November 2015. Published online: 31 December 2015; $\odot$ Inland Fisheries Institute in Olsztyn, Poland Citation: Ulikowski D., Chybowski Ł., Traczuk P. 2015 - Harmful impact of filamentous algae (Spirogyra sp.) on juvenile crayfish - Arch. Pol. Fish. 23: 223-226.

\begin{abstract}
The aim of this study was to determine the impact of filamentous algae on the growth and survival of juvenile narrow-clawed crayfish, Astacus leptodactylus (Esch.), in rearing basins. Three stocking variants were used: A - basins with a layer of filamentous algae without imitation mineral substrate; B - basins with a layer of filamentous algae with imitation mineral substrate; $\mathrm{C}$ - basins without filamentous algae but with mineral substrate. The crayfish were reared from June 12 to October 10 under natural thermal conditions and fed a commercial feed. The results indicated that the presence of the filamentous algae did not have a statistically significant impact on the growth of the juvenile crayfish $(\mathrm{P}>$ 0.05). The presence of the filamentous algae had a strong negative impact on juvenile crayfish survival and stock biomass $(\mathrm{P}<0.05)$. The layer of gravel and small stones that imitated the mineral substrate of natural aquatic basins somewhat neutralized the disadvantageous impact the filamentous algae had on the crayfish.
\end{abstract}

Keywords: Astacus leptodactylus, crayfish, filamentous algae, Spirogyra

Spirogyra sp. are often found in Polish waters. These aquatic filamentous algae of the genus Spirogyra have a cosmopolitan distribution and includes over 600 freshwater species. They prefer shallow, well-oxygenated, well-insolated parts of aquatic

\footnotetext{
D. Ulikowski [ ڤ], Ł. Chybowski, P. Traczuk

Department of Lake Fisheries in Giżycko

Inland Fisheries Institute in Olsztyn, Poland

ul. Rajska 2, 11-500 Giżycko

e-mail: ulikowski@infish.com.pl
}

basins-ditches, streams, ponds, rivers, and lakes. They can form loose or more compact floating aggregations in the water column or on the surface, but mostly they cover stones, gravel, submerged tree trunks and roots, aquatic plants, and other objects found on the bottom. They often form slippery, velvety, pale green fronds on these substrate, which is why they are commonly referred to in English as water silk or mermaid's tresses. These algae can grow very rapidly in nutrient-rich, well-insolated waters. They reproduce either vegetatively through the decay of strands into single cells that give rise to new strands, or sexually through scalariform conjugation (Gumiński 1990, Kawecka and Eloranta 1994).

Spirogyra can be consumed by protozoa, mollusks, and by some species of fish and waterfowl, but their ecological role as food is poorly understood (Kawecka and Eloranta 1994). They have also been detected in the digestive tracts of crayfish (Kossakowski 1966 Holdich 2002), but it is likely that they were consumed accidentally when the crayfish were feeding on larval insects and mollusks entangled in the filamentous algae. Periphyton do not settle on filamentous algae, which is probably a consequence of their allelopathic interactions, including bactericidal properties (Kawecka and Eloranta 1994). The dead fronds of filamentous algae can also contaminate waters, including drinking water sources, with the products of their decomposition.

\footnotetext{
C Copyright by Stanisław Sakowicz Inland Fisheries Institute in Olsztyn.

(c) 2015 Author(s). This is an open access article licensed under the Creative Commons Attribution-NonCommercial-NoDerivs License (http://creativecommons.org/licenses/by-nc-nd/3.0/).
} 
Dense aggregations of filamentous algae growing on the bottoms of reservoirs greatly hinder the mobility of many aquatic organisms, including crayfish. Filamentous algae often grow on the carapaces of crayfish, and this masking effect is beneficial as it permits crayfish to hide from potential enemies.

Small, shallow ponds are used in crayfish aquaculture to rear juvenile crayfish (Ackefors and Lindqvist 1994, Ackefors 1998, Ulikowski and Krzywosz 2013, Ulikowski et al. 2015). Such basins are particularly prone to heavy filamentous algae growth (Ulikowski 2007). This was the motivation for attempting to answer the question of what impact filamentous algae has on juvenile crayfish. The aim of the experiment was to determine what impact filamentous algae in rearing basins has on the growth and survival of juvenile crayfish.

The experiment was conducted at the Department of Sturgeon Fish Breeding in Pieczarki, which is part of the Inland Fisheries Institute in Olsztyn. The stocking material for the experiment comprised juvenile narrow-clawed crayfish Astacus leptodactylus (Esch.), that had undergone the first molt (stage 2 juvenile) with a mean total length (TL) of $10.8 \pm 1.2$ $\mathrm{mm}$. These specimens were obtained from females kept in breeding ponds through maternal incubation under controlled conditions (Ulikowski and Krzywosz 2005). The initial stocking density was 180 individuals per $\mathrm{m}^{2}$. The experiment was performed in two independent recirculation systems equipped with two similar rotational basins: $\mathrm{X}$ - basins of laminated plastic with a diameter of $1.46 \mathrm{~m}$ and a depth of $40 \mathrm{~cm}$; Y - concrete basins with a diameter of 1.2 $\mathrm{m}$ and a depth of $40 \mathrm{~cm}$. The bottoms of half of the $\mathrm{X}$ basins and all of the $\mathrm{Y}$ basins were covered with gravel and small stones to a thickness of about $10 \mathrm{~cm}$ to imitate the natural mineral substrates of natural aquatic basins. Additionally, 100 plastic tubes were placed on the bottoms of all the $\mathrm{X}$ and $\mathrm{Y}$ basins as hiding places for the crayfish. The recirculating system of the X ponds was not covered so they were exposed to natural sunlight for several hours daily, which facilitated the development of filamentous algae. The second recirculating system with the Y basins was covered to block direct sunlight which prevented the occurrence of filamentous algae. In order to ensure the growth of filamentous algae on the bottoms of the $\mathrm{X}$ tanks, small clumps of algae from ponds were introduced into them two weeks before the crayfish were stocked into the basins; these grew to heights of $15-20 \mathrm{~cm}$. The experiment ran from June 12 to October 10 under natural water thermal conditions.

Description of the experimental variants:

A - three X basins with a layer of filamentous algae without imitation mineral substrate;

B - three Y basins with a layer of filamentous algae with imitation mineral substrate;

C - 12 Y basins without filamentous algae with imitation mineral substrate.

The crayfish were fed once daily after 19:00 (ad libitum) with Perla Larva Proactive 3.0 feed (Skretting, France, with a proximate composition of $62.0 \%$ protein, $11.0 \%$ lipids, $0.8 \%$ fiber, and $10.0 \%$ ash, Ulikowski et al. 2008). Every few days water temperature and oxygenation were measured in both recirculating systems. During the experiment, the water oxygen content at the basin outflows did not drop below $6 \mathrm{mg} \mathrm{dm}^{-3}$, and the thermal conditions were similar in both recirculating systems (differences did not exceed $1.5^{\circ} \mathrm{C}$ ). After the conclusion of the experiment, the crayfish were caught and counted and the stock was weighed to determine biomass. The final stock density, survival, and the percentage of specimens with cheliped loss (S) were calculated. Next, a sample of specimens was collected from each experimental variant for weighing (W) and measuring total length (TL) and carapace length (CL). The measurements were performed on live specimens. First, the crayfish were weighed, and then, using the image analysis program MultiScan 8.1, they were measured (TL and CL) using the estimation method by Ulikowski and Krzywosz (2009). The results of body length measurements were used to calculate the TL/CL proportions. Additionally, values of the coefficient of variation (CV) for TL/CL proportion $(\mathrm{CV}(\%)=100 \times($ standard deviation $\times$ means value ${ }^{-1}$ ) were calculated. The significance of the differences between means was tested with Statistica 7.1 (Statsoft, Poland) using analysis of 
Table 1

Impact of the presence of filamentous algae (Spirogyra sp.) on the total body length (TL), carapace length (CL), body weight (W), and the TL/CL length proportion and the coefficient of variation of this proportion (CV) of juvenile narrow-clawed crayfish $(A$. leptodactylus) after four months of rearing in basins in recirculating systems. Variant A - basins with a layer of filamentous algae without imitation mineral substrate; B - basins with a layer of filamentous algae with imitation mineral substrate; C - basins without filamentous algae but with mineral substrate. Means in columns with the same letter index do not differ significantly statistically (ANOVA, Tukey's post hoc test $\mathrm{P}<0.05$ )

\begin{tabular}{|c|c|c|c|c|c|c|c|c|c|c|c|c|}
\hline \multirow[b]{2}{*}{ Variant } & \multirow[b]{2}{*}{$\mathrm{n}$} & \multicolumn{3}{|c|}{$\mathrm{TL}(\mathrm{mm})$} & \multicolumn{3}{|c|}{ CL (mm) } & \multicolumn{3}{|c|}{ W (mg) } & \multirow[b]{2}{*}{ TL/CL } & \multirow[b]{2}{*}{ CV (\%) } \\
\hline & & mean & SD & $\min -\max$ & mean & SD & $\min -\max$ & mean & SD & $\min -\max$ & & \\
\hline A & 121 & $29.6^{\mathrm{a}}$ & 4.6 & $20.6-41.5$ & $15.8^{\mathrm{a}}$ & 2.3 & $11.0-23.0$ & $865^{\mathrm{a}}$ & 414 & $262-2208$ & 1.88 & 5.2 \\
\hline B & 162 & $30.8^{\mathrm{a}}$ & 5.3 & $20.2-46.2$ & $15.9^{\mathrm{a}}$ & 2.6 & $10.6-22.4$ & $893^{\mathrm{a}}$ & 545 & $236-2249$ & 1.94 & 4.8 \\
\hline C & 62 & $30.8^{\mathrm{a}}$ & 4.8 & $18.9-45.8$ & $16.0^{\mathrm{a}}$ & 2.3 & $9.6-24.0$ & $855^{\mathrm{a}}$ & 324 & $220-1933$ & 1.92 & 5.0 \\
\hline
\end{tabular}

Table 2

Impact of the presence of filamentous algae (Spirogyra sp.) on stocking density, biomass, survival, and the percentage share of individuals with cheliped loss (S) of juvenile narrow-clawed crayfish (A. leptodactylus) after four months of rearing in basins in recirculating systems. Description of the variants - see Table 1. Differences among means marked with different letter indexes in the columns are statistically significant (ANOVA, Tukey's post hoc test $\mathrm{P}<0.05$ )

\begin{tabular}{|c|c|c|c|c|c|c|c|c|c|c|}
\hline \multirow[b]{2}{*}{ Variant } & \multirow{2}{*}{$\begin{array}{l}\text { Number } \\
\text { of } \\
\text { replicates }\end{array}$} & \multirow{2}{*}{$\begin{array}{l}\text { Initial } \\
\text { stocking } \\
\text { density } \\
\text { (ind. } \mathrm{m}^{-2} \text { ) }\end{array}$} & \multirow{2}{*}{$\begin{array}{l}\text { Final } \\
\text { stocking } \\
\text { density } \\
\text { (ind. } \mathrm{m}^{-2} \text { ) }\end{array}$} & \multicolumn{3}{|c|}{ Biomass $\left(\mathrm{g} \mathrm{m}^{-2}\right)$} & \multicolumn{3}{|c|}{ Survival (\%) } & \multirow[b]{2}{*}{$S(\%)$} \\
\hline & & & & mean & SD & $\min -\max$ & mean & SD & $\min -\max$ & \\
\hline A & 3 & 180 & 36 & $31.5^{a}$ & 7.4 & $25.3-39.7$ & $20.2^{\mathrm{a}}$ & 3.9 & $17.7-24.7$ & 4.3 \\
\hline B & 3 & 180 & 58 & $52.1^{\mathrm{b}}$ & 8.1 & $44.6-60.7$ & $32.6^{\mathrm{b}}$ & 5.7 & $28.0-30.0$ & 5.3 \\
\hline $\mathrm{C}$ & 12 & 180 & 110 & $93.8^{\mathrm{c}}$ & 5.5 & 86.4-103.7 & $61.2^{\mathrm{c}}$ & 3.6 & 56.3-67.7 & 18.0 \\
\hline
\end{tabular}

variance (ANOVA, $\mathrm{P}<0.05$ ). If significant differences were noted, Tukey's post hoc test was applied for different $\mathrm{n}$ samples.

The results of individual measurements indicated that the impact of filamentous algae did not have a statistically significant impact on the growth of juvenile crayfish $(\mathrm{P}>0.05)$. The final mean values of total body length (TL), carapace length (CL), and body weight $(\mathrm{W})$ were similar in all stocking densities (Table 1). The calculated values of the TL/CL proportion for four-month-old crayfish ranged from 1.88 to 1.94. These are higher than values obtained for younger specimens (one- and two-month olds) from basin rearing (Ulikowski and Krzywosz 2006, 2009). However, according to several sources, the values of this proportion in adults is from 1.90 to 1.96 in males and from 2.00 to 2.05 for females (Kossakowski 1962, Andrzejewski et al. 2001, Chybowski 2007).
These examples indicate that the values of the TL/CL proportion increase as the crayfish age.

Filamentous algae had a strong negative impact on crayfish $(P<0.05)$. Survival in variant $C$ was threefold higher than it was in variant $\mathrm{A}$ and twofold higher than in variant $B$. The final stock biomass exhibited similar trends (Table 2). The layer of gravel and small stones imitating the mineral substrate of natural basins partially neutralized the harmful impact the filamentous algae had on the crayfish. The results were also confirmed by observations made during rearing; in basins in which filamentous algae occurred (variants A and B) crayfish deaths were observed during molting. The juvenile crayfish became entangled in the alga fronds, and since they were weakened by molting they were not able to extricate themselves and they died after a certain time. Deaths were also noted in these basins when part of the 
filamentous algae died off. They probably emitted a substance that was harmful to the crayfish. Observations also indicated that the crayfish stayed near the sides and the bottoms of the basins to avoid the thick aggregations of filamentous algae.

A greater percentage share of specimens with missing chelipeds $(S)$ were noted in variant $C$ than in the other variants (A and B), and this resulted from the higher stocking density that resulted from the higher stock survival (Table 2). The experiment indicated that filamentous algae had a strong negative impact on the survival of juvenile crayfish. However, the presence of filamentous algae did not significantly impact crayfish growth.

Acknowledgments. The study was conducted as part of statutory project no. S-011 at the Inland Fisheries Institute in Olsztyn, Poland.

Author contributions. D.U. designed and performed the research, D.U., Ł.Ch. analyzed the data, D.U., Ł.Ch., and P.T. wrote the paper.

\section{References}

Ackefors H. 1998 - The culture and capture crayfish fisheries in Europe - World Aquaculture 29: 18-24, 64-67.

Ackefors H., Lindqvist O.V. 1994 - Cultivation of freshwater crayfishes in Europe - In: Freshwater crayfish aquaculture in North America, Europe, and Australia: families Astacidae, Cambaridae and Parastacidae (Ed.) J.V. Huner. Food Products Press, NY, London, Norwood: 157-216.

Andrzejewski W., Czarnecki M., Mastyński J. 2001 Morphometric features of crayfish (Astacus leptodactylus Esch.) coming from Gaj Lake - Anim. Sci. 3: 47-55.

Chybowski Ł. 2007 - Morphometrics, fecundity, density, and feeding intensity of the spinycheek crayfish, Orconectes limosus (Raf.) in natural conditions - Arch. Pol. Fish. 15: 175-241.

Gumiński S. 1990 - Physiology of algae and cyanobacteria Wyd. Uniwersytetu Wrocławskiego, Wrocław: 148 p. (in Polish).

Holdich D.M. 2002 - Biology of freshwater crayfish Blackwell Science, Oxford: 682 p.

Kawecka B., Eloranta P.V. 1994 - Overview of the algal ecology of freshwater and terrestrial environments - Wyd. Nauk. PWN, Warszawa: 192 p. (in Polish)

Kossakowski J. 1962 - A comparison of several morphometric indices of three crayfish species of Polish waters - Rocz. Nauk Rol. 81-B-2: 359-376 (in Polish).

Kossakowski J. 1966 - Crayfish - PWRiL, Warszawa: 292 p. (in Polish)

Ulikowski D., Krzywosz T. 2005 - Comparison of various methods for obtaining larval crayfish based on the example of the narrow-clawed crayfish (Astacus leptodactylus Esch.) - In: Reproduction, rearing, and prophylactics of Siluriformes and other fish species. (Ed.) Z. Zakęś, Wyd. IRS, Olsztyn: 237-240 (in Polish).

Ulikowski D. 2007 - Crayfish in Lithuania: Management and conservation - Komun. Ryb. 5: 8-10 (in Polish).

Ulikowski D., Krzywosz T. 2006 - Impact of food supply frequency and the number of shelters on the growth and survival of juvenile narrow-clawed crayfish (Astacus leptodactylus Esch.) - Arch. Pol. Fish. 14: 225-241.

Ulikowski D., Krzywosz T. 2009 - In vivo calibration of juvenile crayfish body length and weight with a photographic-computer method - Arch. Pol. Fish. 17: 89-93.

Ulikowski D., Krzywosz T. 2013 - Innovation in crayfish hatchery - In: Innovation in the hatchery of aquatic organisms (Eds.) Z. Zakęś, K. Demska-Zakęś, A. Kowalska, Wyd. IRS, Olsztyn: 271-281 (in Polish).

Ulikowski D., Krzywosz T., Traczuk P., Kozłowski M. 2008 Evaluation of the suitability of three commercial fish feeds for rearing juvenile narrow-clawed crayfish (Astacus leptodactylus) - In: Biotechnology in aquaculture (Ed.) Z. Zakęś, Wyd. IRS, Olsztyn: 339-345 (in Polish).

Ulikowski D., Chybowski Ł., Traczuk P. 2015 - Rearing crayfish - challenges, achievements, perspectives - In: Rearing aquatic organisms - challenges, achievements, perspectives (Eds) Z. Zakęś, K. Demska-Zakęś, A. Kowalska, Wyd. IRS Olsztyn: 87-96 (in Polish). 